\title{
PENYULUHAN PENCEGAHAN MENIKAH USIA ANAK DI KECAMATAN CURUG KOTA SERANG
}

\author{
Rika Kartika $^{1}$ Gatot Hartoko $^{2}$, Iis Nurasiah ${ }^{3}$ \\ ${ }_{1,2,3}$ Universitas Bina Bangsa Banten \\ E-mail: ${ }^{1}$ rikakartika.binabangsa@gmail.com, ${ }^{2}$ gatothartoko.binabangsa@gmail.com, \\ 3iisnurasiah.binabangsa@gmail.com
}

\begin{abstract}
Abstrak
Pernikahan yang terjadi di usia anak merupakan salah satu permasalahan nasional, di Indonesia. Angka pernikahan usia anak di Indonesia cukup tinggi. Usia anak diperbolehkan menikah baik pria maupun wanita dengan usia minimum 19 tahun. Namun, usia 19 tahun ini masih termasuk dalam usia remaja yang terlalu dini bila memutuskan untuk menikah karena belum mampu mengendalikan diri dengan baik. Berdasarkan data BKKBN tahun 2014 di Provinsi Banten terdapat 6,5\% wanita menikah usia anak yaitu dibawah usia 15 tahun. Di Kampung Cibeo yang merupakan salah satu kampung di Kecamatan Curug menunjukkan bahwa terdapat 62,2\% wanita yang menikah di usia anak dari 45 sampel. Pernikahan usia anak berdampak dapat terganggunya kesehatan baik jasmani maupun psikoogis anak. Pengabdian kepada masyarakat ini bertujuan untuk memberikan edukasi kepada masyarakat di Kecamatan Curug, seperti Kelurahan Kemanisan, Pancalaksana, dan Tinggar, terkait pernikahan di usia anak. Edukasi yang diberikan ini menggunakan metode penyuluhan melalui kegiatan penyuluhan secara virtual secara online, menggunakan platform zoom meeting. Adanya penyuluhan pencegahan pernikahan di usia anak mampu membuka pola pikir, menambah wawasan dan pengetauhuan terkait pernikahan di usia muda sehingga masyrakat Curug, khususnya kaum remaja dapat mempertimbangkan sebelum mengambil keputusan untuk menikah di usia anak.
\end{abstract}

Kata kunci: Edukasi, Penyuluhan, Pernikahan Usia Anak; Psikologis Anak; Pengendalian Diri

\begin{abstract}
Marriage that occurs at the age of a child is one of the national problems, in Indonesia. The rate of child marriage in Indonesia is quite high. Children are allowed to marry both male and female with a minimum age of 19 years. However, the age of 19 is still a teenager which is too early to decide to get married because he has not been able to control himself well. Based on data from the 2014 BKKBN in Banten Province, $6.5 \%$ of women married at the age of children, namely under the age of 15 years. In Cibeo Village which is one of the villages in Curug District, it shows that there are $62.2 \%$ of women who married at the age of children from 45 samples. Child marriage has an impact on the health of the child, both physically and psychologically. This community service aims to provide education to the community in Curug District, such as Kemanisan, Pancalaksana, and Tinggar Villages, regarding child marriage. The education provided uses the extension method through online penyuluhan secara virtuals, using the zoom meeting platform. The existence of counseling on prevention of marriage at a child's age is able to open a mindset, add insight and knowledge related to marriage at a young age so that the Curug community, especially teenagers, can consider before making a decision to marry at a child's age.
\end{abstract}

Keywords: Education, Counseling, Child Marriage; Child Psychology; Self-control

\section{PENDAHULUAN}

Dalam perkembangannya, usia anak menjadi kategori dewasa akan banyak mengalami perubahan, bukan hanya dari pola pikir, namun dari sisi biologis dan psikologis. Usia remaja adalah salah satu perkembangan yang akan dialami oleh setiap individu sebelum 
menuju ke usia dewasa. Menurut Hurlock (1993) remaja adalah fase perubahan dari manusia baik secara mental maupun fisik yaitu dari dari kanak- kanak menjadi dewasa. Dalam usia remaja terdapat peluang yang bernilai karena banyak potensi yang dapat digali dan dikembangkan sehingga dapat dimanfaatkan untuk meningkatkan intelektual, wawasan, ekonomi, dan pengalaman- pengalaman dalam hal yang positif.

Remaja yang dapat mengelola dirinya sendiri dengan tepat, secara tidak langsung dapat memberikan kesiapan akan mentalnya untuk menuju ke usia dewasa. Menurut Monks \& Hadinoto (1992) berpendapat bahwa batas usia remaja yaitu usia dua belas tahun hingga dua puluh satu tahun. Bagi individu yang berada pada masa remaja dan masih memiliki anugerah kesempatan untuk menerima pendidikan di bangku sekolah, umumnya dunia remaja akan dikelilingi dengan keinginan untuk mempelajari dan mengerjakan tugas dari setiap subjek mata pelajaran. Namun, pada masa remaja mulai timbul rasa keingintahuan yang tinggi, dan rasa ingin mencoba melakukan sesuatu yang baru yang dianggap sebagai tantangan.

Di masa pandemi covid -19 ini, berdampak pada dunia pendidikan sebab kini umumnya kegiatan pendidikan menerapkan model pembelajaran secara digital yaitu belajar dari rumah secara daring, contoh media pembelajaran yang dapat digunakan yaitu seperti zoom, google meet, dan lain sebagainya. Pembelajaran secara daring ini tentunya bertujuan untuk meminimalisir dari terpaparnya virus covid-19. Namun, tak sedikit tantangan yang dihadapi seperti jaringan internet yang buruk, tidak memiliki perangkat atau gedget untuk mengakses zoom, google meet, bahkan terkendala akan biaya untuk memiliki kuota internet. Dampak pandemi covid-19 ini, dapat mendorong terjadinya pernikahan usia anak. Berdasarkan informasi dari CNN menurut Bapak Hasto W bahwa salah satu bencana sosial adalah terjadinya pernikahan usia anak (Anggraeni, 2020).

Menurut Undang-Undang No. 16 Tahun 2019 Pasal 7 Ayat 1 bahwa usia diperbolehkan menikah untuk laki-laki dan perempuan yaitu minimum usia 19 tahun. Berdasarkan ketentuan Undang- Undang tersebut merupakan hasil revisi dari Undang-Undang No 1 Tahun 1974 yang semula usia minimum wanita menikah yaitu 16 tahun dan kini seteah adanya perubahan menjadi 19 tahun. Revisi atas undang-undang ini sebetulnya menunjukkan bahwa salah satu bentuk upaya dari pemerintah untuk dapat menurunkan angka usia pernikahan usia anak yang cukup tinggi di Indonesia.

Berdasarkan data Badan Kependudukan dan Keluarga Berencana (BKKBN) tahun 2014, menurut Marta selaku Sekertaris Jendral PBB untuk UNICEF bahwa di Indonesia data persentase pernikahan usia anak yaitu dengan usia 18 tahun kebawah mencapai angka 25\%, bahkan mencapai $46 \%$ dari total yang menikah dengan usia wanita menikah 15 tahun hingga 19 tahun dan pada Provinsi Banten terdapat sekitar 6,5\% untuk wanita yang menikah sebelum usia mencapai 15 tahun (Rustandy, 2018). Berdssarkan data Susenas (2018) dalam BPS, UNICEF, \& PUSKAPA (2020) menunjukkan bahwa kelompok pria dan wanita yang tidak melanjutkan sekolah karena menikah sebelum usia 18 tahun ada sebesar 91,04\% dan 93,60\%. Pernikahan yang terjadi sebelum usia mencapai 18 tahun bagi wanita yang mendapatkan pendidikan tertinggi hanya sampai Sekolah Dasar sebesar 33,95\%, SMP $44,86 \%$, SMA $11,76 \%$ dan pria yang mendapatkan pendidikan tertinggi hanya sampai Sekolah Dasar sebesar 36,61 \%, SMP 32,25\%, SMA 19,23\%. Data tersebut menunjukkan bahwa pernikahan usia anak menyebabkan anak tidak mampu untuk dapat melanjutkan pendidikan ke jenjang yang lebih tinggi.

Begitupun, pada Kecamatan Curug Kota Serang- Banten, data pernikahan usia dini di 
Kecamatan Curug dalam kurun waktu enam bulan periode Januari hingga Juli 2021 bahwa yang mengajukan dispensasi pernikahan atau pernikahan yang terjadi sebelum usia 19 tahun sebanyak 3, pernikahan yang terjadi usia 19- 21 tahun sebanyak 54. Kecamatan Curug merupakan salah satu kecamatan yang ada di Kota Serang terdiri dari beberapa kelurahan, diantaranya yaitu Kelurahan Kemanisan, Kelurahan Pancalaksana, dan Kelurahan Tinggar. Berdasarkan fenomena yang ada di Kelurahan Pancalaksan, menurut Bapak Darmat, SE Selaku Sekertaris Lurah menagatakan bahwa terdapat usia remaja yaitu 17 tahun yang ingin mengajukan membuat surat pengantar nikah, meskipun pada akhirnya dari pihak kelurahan tidak mensetujui. Selain itu, berdsarkan hasil penelitian Rahman (2019) yang dilakukan di Kampung Cibeo yang merupakan salah satu kampung yang ada di Kecamatan Curug menunjukkan bahwa dari 45 sampel wanita di Kampung Cibeo terdapat 28 sampel wanita yang melakukan pernikahan usia anak atau sekitar $62,2 \%$. Selain itu sebesar 76,7\% dari 45 sampel wanita menunjukkan bawha wanita di dukung keluarga untuk melakukan pernikahan di usia anak. Data tersebut menunjukkan angka yang cukup tinggi.

Pernikahan usia anak ini, kerap kali terjadi juga disebabkan minimnya pengetahuan para remaja terkait pernikahan. Pola pikir dalam fase remaja pun dapat memicu keinganan untuk merasa lebih mandiri dalam menyikapi segala hal sehingga dapat mendorongnya keinginan untuk menikah di usia anak. Rendahnya tingkat pendidikan pun menajdi salah satu pendorong terjadinya pernikahann usia anak, sebab bila anak medapatkan pendidkan yang cukup, dengan pendidikan dapat membuka wawasan berfikir, mempertimbangkan dalam mengambil keputusan, termasuk keputusan untuk menikah. Rendahnya taraf ekonomi juga dapat memicu wanita usia anak untuk lebih memilih menikah dibandingkan melanjutkan pendidikan.

Menurut Manan (1989) komponen fundametal yang selalu beriringan dengan individu adalah pendidikan. Adanya pendidikan dapat memberikan terbukanya wawasan untuk dapat menjadi individu yang lebih baik terutama dalam pola pikir untuk mempertimbangkan setiap keputusan yang diambil. Oleh sebab itu termasuk penting untuk dilakukannya edukasi kepada msayarakat dalam uapaya menekan angka pernikahan usia anak di Kecamatan Curug, yaitu memberikan edukasi dari segi hukum dan kesehatan dengan cara melakukan Penyuluhan Pencegahan Menikah Usia Anak.

\section{METODE PELAKSANAAN}

Upaya yang dilakukan untuk memberikan edukasi kepada masyarakat di Kecamatan Curug Kota Serang- Banten dalam mencegah terjadinya pernikahan usia anak yaitu dengan memberikan penyuluhan yang ditinjau dari segi hukum dan kesehatan. Kegiatan penyuluhan ini ditujukkan untuk masyarakat umum di Kecamatan Curug khususnya kaum remaja.

Kegiatan ini dilakukan secara daring/ virtual dengan memanfaatkan platform zoom meeting. Penyampain materi dibagi kedalam dua sesi, sesi pertama pemaparan materi pernikahan usia anak dari aspek hukum dan sesi kedua pemaparan materi pernikahan usia anak dari aspek kesehatan. Acara Penyuluhan secara virtual ini dimulai pukul 09.00 WIB hingga pukul 12.00 WIB. Di setiap sesi, setelah pemateri memberikan pemaparan, secara langsung dibuka sesi pertanyaan, begitupun pada sesi kedua. Acara penyuluahan virtual ini di dukunng oleh beberapa perwakilan mahasiswa dan mahasiswi Universiitas Bina Bangsa. 
Kegiatan penyuluhan ini menghadirkan dua oraang narasumber yang berkompeten dibidangnya, bila ditinjau dari aspek hukum, materi pernikahan usia anak disampaikan oleh Bapak Mohammad Hifni, SH.I., M.Sy, selaku Dosen Fakultas Hukum Universitas Bangsa dan bila ditinjau dari aspek kesehatan pemataran materi dilakukan oleh Ibu Aprilia Rahmawati selaku Kasubag TU UPT Puskesmas Kecamatan Curug. Acara penyuluhan secara virtual ini, di pandu oleh Moderator yaitu Ibu Rika Kartika, S.T., M.Ak dan Ibu Iis Nurasiah, SE., MM, serta dibuka secara langsung oleh Bapak Drs. Gatot Hartoko, M.Si dan Bapak Ahmad Nuri, S.H. M.Si selaku Kepala Kecamatan Curug.

\section{HASIL DAN PEMBAHASAN}

Pelaksanaan kegiatan penyuluhan ini berjalan dengan lancar. Pemaparan materi yang disampaikan oleh kedua narasumber sangat bagus sekali untuk dapat membuka wawasan dan menambahah pengetahuan peserta khususnya kaum remaja terkait pernikahan. Acara penyuluhan secara virtual ini nampak hidup dan interaktif antara narasumber, moderator dan peserta. Dalam sesi tanya jawab, baik dari aspek hukum maupun kesehatan, peserta penyuluhan secara virtual antusias dalam mengajukan pertanyaan- pertanyaan seputar materi. Penyuluhan secara virtual ini dihadiri oleh 74 peserta.

Berdsarkan hasil evaluasi atas acara ini, dapat dikatakan berhasil. Hal ini ditandai dengan begitu banyaknya pertanyaan dari peserta, menunjukkan bahwa materi yang dsampaikan oleh pemateri dapat dipahami oleh peserta, sehingga begitu tinggi keingintahuan yang lebih dari peserta terkait materi yang disampaikan. Pemateri mampu memberikan jawabanjawaban secara jelas atas setiap pertanyaan. Sehingga, peserta lebih dapat memahami isi materi yang disampaikan dan sekaligus menambah wawasan tentang resiko menikah usia anak.

Dalam Undang- Undang No 16 Tahun 2019 Pasal 7 ayat 2 diperkenankan untuk mengajukan permohonan atas dispensasi menikah dengan syarat, misal karena mendesak dan disertai penjelasan dari kedua orangtua mengenai alasan yang menyababkan akan menikahi anaka di usia anak, disertai evidence yanng mendukung.

Namun demikian, menikah usia muda rentan beresiko tinggi, hal ini disebabkan karena pada anak usia anak atau dibawah 19 tahun masih dalam fase remaja belum cukup mampu mengendalikan diri dengan optimal, sehingga dapat memicu terjadinya pelanggaran terhadap hak-hak anak bahkan hak asasi manusia, seperti terjadinya kekerasan dalam berumah tangga (KDRT), KDRT ini pun dapat memicu terjadinya perceraian.

Selain itu, pernikahan yang dilakukan di usia anak juga dapat memicu resiko dari segi kesehatan, dalam hal ini karena wanita menikah di usia anak, kondisi rahim masih rentan sekali sehingga dapat beresiko tinggi terjadinya, keguguran, bayi prematur, bahkan dapat menyebabkan kematian ibu saat melahirkan. Dampak pernikahan usia anak bila ditinjau dari sisi pria yaiitu dapat menimbulkan tingkat stres yang tinggi karena di usia anak, seorang pria sudah menanggung beban untuk memimpin keluarga kecilnya dan mencukupi perekonomian keluarga, sehingga berdampak juga pada munculnya pekerja dibawah umur yang notabene belum cakap dalam bekerja.

Apabila ditinjau dari sisi anak bila lahir dari orang tua yang menikah usia anak yaitu dapat memicu meningkatnya data kondisi anak yang mengalami stunting, gizi buruk, apabila taraf ekonomi masih rendah dapat berdampak pada terhambatnya pendidikan bagi anak sebagai generasi penerus bangsa. . Pelaksanaan Penyuluhan secara virtual Penyuluhan Pencegahan 
Pernikahan Usia Anak dapat dilihat pada Gambar dibawah ini.

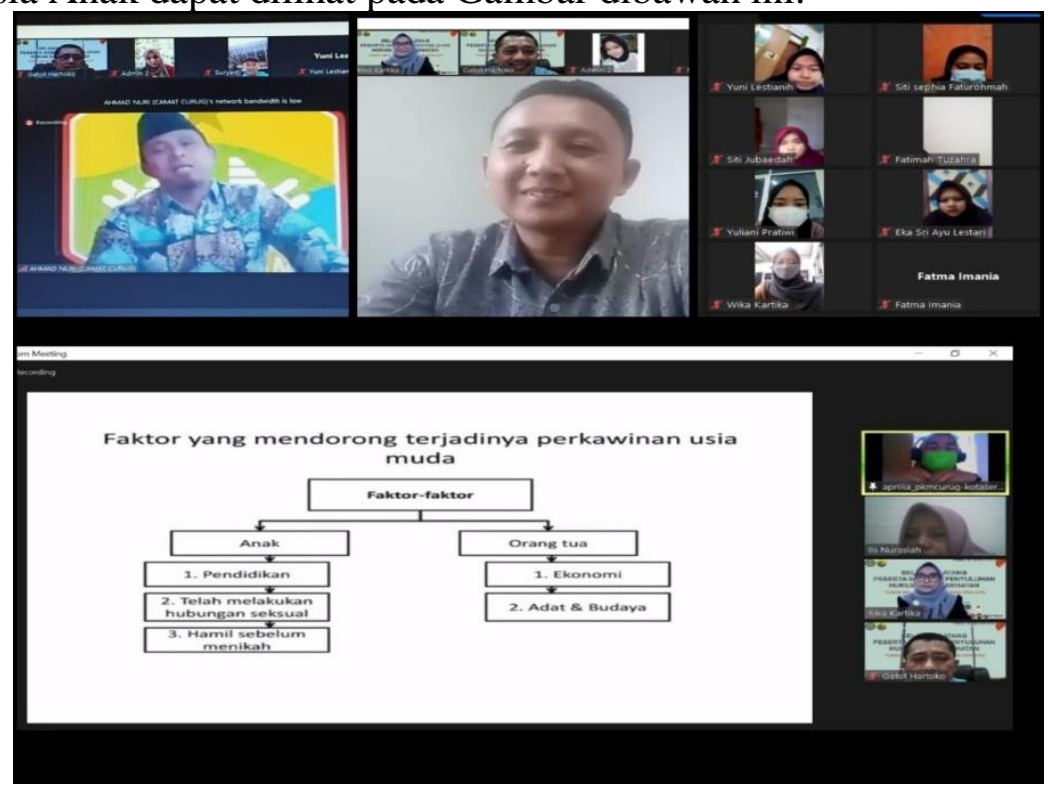

Gambar 1. Penyuluhan secara virtual Penyuluhan Pencegahan Pernikahan Usia Anak

\section{KESIMPULAN}

Pernikahan dini adalah pernikahan yang diperbolehkan dengan mnimum usia 19 tahun, bila ingin menikah dibawah usia 19 tahun dapat melakukan pengajuan dispensasi pernikahan ke pengadilan agama, namun dengan syarat alasan yang jelas khususnya dari orang tua anak. Peraturan yang sudah ditentukan tersebut memang masih termasuk dalam kategaori usia remaja, sehingga pernikahan yang dilakukan di usia anak sangat beresiko tinggi. Hal ini disebabkan pada fase anak usia anak belum cukup mampu dalam mengatasi resiko yang terjadi karena umumnya pengendalian diri yang masih rendah.

Adanya penyuluhan hukum dan kesehatan terkait pernikahan usia anak, sangat bermanfaat karena ilmu yang diperoleh dari penyuluhan secara virtual ini bisa menjadi bahan pertimbangan bagi para remaja sebelum memutuskan untuk menikah. Usia remaja fase dimana anak sebegai generasi penerus yang lebih baik dari orang tua, sehingga perlu memperhatikan upaya untuk mewujudkan cita-cita, dengan semangat belajar dan menunda menikah di usia anak.

Berdasarkan pada hasil acara penyuluhan secara virtual yang telah dilakukan, artinya sangat perlu edukasi berkelanjutan dalam upaya meminimasi atau mencegah terjadinya pernikahan usia anak. Bagi para remaja sebaiknya lebih meningkatkan keimanan dan ketqwaan agar faktor-faktor penyebab pernikahan usia anak dapat dihindari, sehingga dapat menekan angka pernikahan di usia anak.

Sebaiknya,untuk setiap individu menikah ketika pria dan wanita sudah siap dan sudah cukup mampu mengendalikan diri dalam menghadapi setiap persoalan yang terjadi. Bila masih bersekolah, sebaiknya berusaha untuk terus fokus dalam belaja agar berhasil mendapatkan pekerjaan yang diharapkan, sehingga dapat merubah kondisi perekonomian lebih baik, agar ketika menikah, sudah siap untuk bisa hidup mandiri bersama keluarga kecil dengan harmonis dan sejahtera.

Namun, apabila pernikahan dalam usia anak mendesak harus terjadi, diupayakan untuk dapat mengikuti program pemerintah yaitu keluarga berencana dengan cukup memiliki dua anak. 


\section{DAFTAR PUSTAKA}

Anggraeni, T. (2020, October 21). Kasus Pernikahan Dini Meningkat Selama Masa Pandemi. Yoursay.Suara.Com. https://yoursay.suara.com/news/2020/10/21/110151/kasus-pernikahan-dini-meningkatselama-masa-pandemi

BPS, UNICEF, \& P. (n.d.). Pencegahan Perkawinan Anak Percepatan yang Tidak Bisa Ditunda.

Hurlock, E. B. (1993). Psikologi Perkembangan : Suatu Pendekatan Sepanjang Rentang Kehidupan (Edisi Kelima). Erlangga.

Manan. (1989). Antropologi Pendidikan. Departemen Pendidikan dan Kebudayaan Direktorat jenderal Pendidikan Tinggi Proyek Pengembangan Lembaga Pendidikan Tenaga Kependidikan.

Monks, F.J., Knoers, A. M. ., \& \& Hadinotot S.R. (1992). Psikologis Perkembangan: Pengantar dalam berbagai Bagiannya. Gajah Mada University Pers.

Rahman, N. S. (2019). Hubungan Dukungan Keluarga Dan Budaya Dengan Pernikahan Usia Dini Pada Perempuan Di Kampung Cibeo Kelurahan Kemanisan Kota Serang Tahun 2018. Jurnal IImiah Kesehatan Delima, 3(1).

Rustandy, M. (2018). Indonesia dan Pernikahan Dini: Tak Seindah Romeo dan Juliet. Sekolah Non Formal FEB UI. http://snf-febui.com/2018/12/08/childrens-rights-problem-1pernikahan-dini/

Undang- Undang No 1 Tahun 1974.

Undang-Undang No. 16 Tahun 2019 Pasal 7 Ayat 1. 